\title{
Developing a strategy for the terrestrial amphibians and reptiles of Scotland
}

\author{
R. Raynor \\ Scottish Natural Heritage, Great Glen House, Leachkin Road, Inverness IV3 8NW \\ E-mail: Robert.raynor@nature.scot
}

\section{INTRODUCTION}

Scotland's amphibians and reptiles face a variety of threats, and in order to safeguard them for future generations we need to take a coordinated and planned approach. To facilitate this Scottish Natural Heritage (SNH) has been developing a more strategic approach for their future conservation. An outline "proto" strategy is presented, which describes the current situation, the main threats and opportunities, and the reasons why action is needed. The final version of the strategy will be an $\mathrm{SNH}$ document, but the intention is for it to form a framework for future herpetofauna conservation action in Scotland. Once finalised, an implementation plan will be produced to support delivery. With or without a strategy, amphibians and reptiles have intrinsic value in their own right as part of our natural heritage, playing an important role in ecosystems, so we have a moral responsibility to conserve them.
\end{abstract}

\section{STRATEGY}

The overall aim of the strategy is to support the delivery of healthy, self-sustaining populations of all native amphibians and reptiles, and to reverse previous declines where applicable. To achieve this, the strategy has three objectives:

1. To improve people's understanding and appreciation of amphibians and reptiles, reduce persecution and build public support for conserving them.

2. To address the range of ecological threats and pressures affecting Scottish amphibians and reptiles.

3. To improve the quality of information we hold on the distribution and status of amphibians and reptiles through appropriate surveillance and monitoring.

The strategy is intended to help guide the work of public bodies, business and voluntary organisations, recognising that a partnership approach between the relevant organisations is required if we are to achieve our objectives. At its core lies the 2020 Challenge for Scotland's Biodiversity (Scottish Government, 2013) and the associated Route Map to 2020 , from which many of the habitat-related actions are derived and the importance of ecological connectivity is highlighted. Projects designed to improve habitat connectivity for reptiles and amphibians contribute to this while benefiting other wildlife generally, and vice versa. Associated benefits to people also ensue where such projects enable improved access to the countryside and urban green space, thereby providing opportunities to connect people with nature. More specialist actions are also required, and these will be detailed in the implementation plan.

A key requirement is a better understanding of the current population status and trends of Scottish reptiles and amphibians, as well as the threats and pressures affecting them. The population status and trends of most species are incompletely understood and, although general long-term declines have been identified in the British herpetofauna since the earlymid 20th century (Beebee et al., 2009), trends for most species in Scotland are less clear. So, while there is evidence of pond losses in the last century and land-use change, the lack of long-term systematic monitoring for most species means that the empirical evidence base for population declines and our understanding of the effects of perceived threats and pressures is often inadequate. Examples of species that are known to be in decline in Scotland include natterjack toad (Bufo/Epidalea calamita) (McInerny \& Minting, 2016) and the European adder (Vipera berus) (Reading et al., 1994; Wilkinson \& Arnell, 2011). Where such knowledge gaps exist there is a need to implement appropriate measures to strengthen existing populations and promote recovery where declines are believed to have taken place.

The strategy recognises that amphibians and reptiles continue to face a variety of threats but highlights the following in particular:

- Habitat loss and fragmentation

- Pollution, eutrophication and pesticides

- Persecution and exploitation

- Non-native species

- Disease

- Climate change 
Habitat loss and fragmentation are considered by the International Union for Conservation of Nature (IUCN) to be the most pervasive threats to amphibians globally. Reversing this through measures designed to improve connectivity and thereby encourage dispersal is regarded as central to achieving greater resilience amongst amphibian and reptile populations. In Scotland, the effects of habitat fragmentation may be most significant in lowland areas, where patches of semi-natural habitat exist within an intensively-farmed or industrial landscape, often with few or no links to other such patches, and the pressure on land for agriculture and urban development is at its greatest. By reinstating the links between these patches, increased gene-flow can take place, thereby countering the effects of isolation. For some species with more southerly distributions, improved habitat connectivity may also prove to be important in facilitating range expansion northward in response to climate change. Such expansion is predicted by climate envelope modelling for species such as the grass snake (Natrix helvetica) (Dunford \& Berry, 2012).

To improve habitat connectivity the strategy refers to potential wildlife corridors, such as former dismantled railway lines, particularly in the Central Lowlands of Scotland, where they exist at high density in some areas. Some have already been redeveloped as long-distance footpaths and/or cycleways (e.g. see Scottish Natural Heritage, Sustrans \& Scottish Canals, 2014), but these uses need not conflict with their potential value for wildlife, provided sufficient habitat along the margins is retained and managed appropriately. The strategy points to the potential benefits of working with organisations responsible for the development and management of paths and cycle-ways constructed around the former railway network.

Other forms of collaboration are identified that have the potential to benefit amphibians and reptiles. There may be different objectives between collaborating organisations, but where common goals exist, benefits can be delivered for several target species. An example of this is Roots of Rockingham, a Back from the Brink project in Northamptonshire, led by Butterfly Conservation (Nature Back From The Brink, 2018). This aims to restore and manage a network of woodland sites, creating more habitat for vulnerable species specifically the chequered skipper (Carterocephalus palaemon), but the habitat management work will also be of benefit to adders. Other opportunities like this need to be explored.

Underpinning all of this is the need to involve people, educate and raise awareness, and to generally improve our knowledge and understanding of the distribution and status of Scottish amphibians and reptiles.

\section{REFERENCES}

Beebee, T.J.C., Wilkinson, J.W. \& Buckley, J. (2009). Amphibian declines are not uniquely high amongst the vertebrates: trend determination and the British perspective. Diversity 1, 67-88.

Dunford, R.W. \& Berry, P.M. (2012). Climate Change Modelling of English Amphibians and Reptiles: Report to Amphibian and Reptile Conservation Trust (ARC-Trust) Final Report: May 2012. https://www.researchgate.net/publication/261 680126_Climate_change_modelling_of_English_a mphibians_and_reptiles_Report_to_Amphibian_a nd_Reptile_Conservation_Trust_ARC-Trust

McInerny, C.J. \& Minting, P. (2016). The Amphibians and Reptiles of Scotland. Glasgow Natural History Society, Glasgow.

https://www.glasgownaturalhistory.org.uk/boo ks.html

Nature Back From The Brink. (2018). Roots of Rockingham Project. www.naturebftb.co.uk/theprojects/roots-of-rockingham

Reading, C.J., Buckland, S.T., McGowan, G.M., Gorzula, S., Jayasinghe, G., Staines, B.W., Elston, D.A. \& Ahmadi, S. (1994). Status of the Adder Vipera berus in Scotland. Scottish Natural Heritage Research, Survey \& Monitoring Report: 38.

Scottish Government. (2013). 2020 Challenge for Scotland's Biodiversity: a Strategy for the Conservation and Enhancement of Biodiversity in Scotland.

https://www2.gov.scot/resource/0042/004252 76.pdf

Scottish Natural Heritage, Sustrans \& Scottish Canals (2014). National Walking \& Cycling Network Project Plan.

https://www.nature.scot/enjoyingoutdoors/routes-explore/national-walking-andcycling-network

Wilkinson, J.W. \& Arnell, A.P. (2011). NARRS Report 2007-2009: Interim Results of the UK National Amphibian and Reptile Recording Scheme Widespread Species Surveys. Amphibian \& Reptile Conservation Research Report 11/01. https://www.arguk.org/info-advice/surveyand-monitoring/69-narrs-report-20072009/file 